This item was submitted to Loughborough's Research Repository by the author.

Items in Figshare are protected by copyright, with all rights reserved, unless otherwise indicated.

\title{
Infrastructural state capacity for democratization? Voter registration and identification in Côte d'Ivoire and Ghana compared
}

\section{PLEASE CITE THE PUBLISHED VERSION}

http://dx.doi.org/10.1080/13510347.2014.983906

\section{PUBLISHER}

(C) Taylor \& Francis

\section{VERSION}

AM (Accepted Manuscript)

\section{PUBLISHER STATEMENT}

This work is made available according to the conditions of the Creative Commons Attribution-NonCommercialNoDerivatives 4.0 International (CC BY-NC-ND 4.0) licence. Full details of this licence are available at: https://creativecommons.org/licenses/by-nc-nd/4.0/

\section{LICENCE}

CC BY-NC-ND 4.0

\section{REPOSITORY RECORD}

Piccolino, Giulia. 2015. "Infrastructural State Capacity for Democratization? Voter Registration and Identification in Côte D'ivoire and Ghana Compared”. Loughborough University. https://hdl.handle.net/2134/22704. 


\title{
Infrastructural state capacity for democratization? Voter registration and identification in Côte d'Ivoire and Ghana compared
}

\author{
Giulia Piccolino ${ }^{1}$ \\ Institute of African Affairs, German Institute of Global and Area Studies (GIGA), Hamburg, \\ Germany
}

\begin{abstract}
A large portion of electoral irregularities in developing countries stem from administrative deficiencies, rather than deliberate fraud. This is particularly evident when it comes to voter registration and identification: the quality of a voter list depends from the existence of effective mechanisms to register and identify citizens and electors, which might not be easily at hand in many developing countries. Democratization in these countries has been accompanied by intense polemics about the quality of the voter rolls and the identification of electors, which have threatened democratic consolidation. Biometrics technology has been recently heralded as a possible solution, but its effective potential is disputable. In order to understand how problems with registering and identifying voters have affected democratization, this paper reviews the contrasting experiences of Côte d'Ivoire and Ghana. In Côte d'Ivoire, the problem of the reliability of the voter register has been entangled since the '90s with the politicization of the citizenship question. As a consequence, compiling an acceptable voter register has proven extremely difficult and cumbersome. In Ghana, an effective electoral administration has been key to overcome the mistrust of the political parties about the fairness of the voter process.
\end{abstract}

Keywords: voter registration; elections; democratization; state capacity; Ghana; Côte d’Ivoire

8888 words including table

\section{Introduction}

\footnotetext{
${ }^{1}$ Email: giulia.piccolino@giga-hamburg.de
} 
Elections are both "the supreme political act and a routine administrative exercise”. ${ }^{1}$ There is a broad consensus in the academia and among the general public that elections are a necessary condition for a country to be considered democratic. There is also consensus about the fact that not all elections are the same: they can be conducted in a way that ensures that citizens' preferences are duly taken into account, or they can be deeply flawed. Certain standards should be respected, in order for an election to be considered 'free and fair' .

Some of these standards, however, are of a technical and administrative, rather than political or legal, nature. Representative democracy is predicated over the existence of a state that it is able to carry efficiently the administrative aspects of the electoral process. Lack of 'infrastructural power' of the state complicates the process of holding elections and, by consequence, the consolidation of democracy. While there is a growing interest in political science for 'election quality' or 'electoral integrity', ${ }^{2}$ the attention has concentrated on deliberate breaches of electoral rules by politicians wishing to retain or to gain power. ${ }^{3}$ Arguably, however, a large portion of electoral irregularities in developing countries stem from administrative deficiencies, rather than from actors' willingness to manipulate the rules.

In particular, voter registration and identification are the most administratively complex and cumbersome component of an electoral process. The holding of democratic elections requires that a state is able to compile a reliable voter list. It also implies that electors can identify themselves in front of the polling station staff, usually by showing voter cards or national IDs.

In many parts of the developing world, the capacity of states to develop accurate registration and identification systems is in scarce supply. Sub-Saharan Africa is a case in point. In a number of countries, the unreliability of voter registers has raised serious polemics about the fairness of the electoral process. Problems with voter registration stem from the weakness of other mechanisms to identify citizens and cannot thus be easily redressed. A number of solutions have been experimented in recent years, particularly the introduction of computerized biometrics, but their impact is disputed. 
In order to understand the impact of administrative deficiencies on the process of democratization and how countries have overcome them - or failed to - this article discusses the experiences of Côte d'Ivoire and Ghana. The article demonstrates that some of the problems that the two countries have faced in terms of democratic consolidation have been directly related to their deficient registration and identification systems. It then discusses some factors that explain the relative success of Ghana in comparison to Côte d'Ivoire, such as the politicization of the citizenship question in Côte d'Ivoire and the role of the electoral administration.

\section{Democracy, administrative capacity and identification}

Registration techniques and technologies are a key components of the 'infrastructural power' of the state, ${ }^{4}$ which can be defined as "the capacity of the state to penetrate society, regulate social relations, extract resources, and appropriate or use resources in determined way”. ${ }^{5}$ Infrastructural power is distinct from 'despotic' or 'coercive' power. While systems of registration may become tools for state oppression, a state that is able to record and register its citizens is a precondition for the enjoyment of citizenship and of democratic rights. ${ }^{6}$

Effective voter registration is a case in point. The quality of a voter list affects the quality of elections and, in turn, democracy itself. A voter roll can be assessed for its comprehensiveness - the proportion of eligible voters included - its currency - the extent to which information is updated and its accuracy - the rate of error in names, addresses, gender the date of birth. ${ }^{7}$ Many current assessment tools of electoral integrity incorporate indicators of the fairness of voter registration. ${ }^{8}$

Producing a good quality voter roll, however, requires substantial technical and organizational skills. Many Western states have established the administrative capacity necessary to register and identify their citizens before introducing universal suffrage. As a consequence, their arrangements for voter registration capitalise on the existence of other administrative resources, by extracting, for instance, the voter list from the civil register and using national ID cards for identifying voters. This system, however, demands not only that the civil register is accurate, but 
also a high level of trust in state institutions. Even when the civil and voter register are kept separated, the task of updating the register can be facilitated by the sharing of information with other state departments, when good records already exist. ${ }^{9}$

On the other hand, voter registration poses particular challenges in those parts of the world where states struggle to collect reliable data about their citizens, ${ }^{10}$ such as in Sub-Saharan Africa. These countries have typically deficient systems of civil registration and large sections of the population that do not hold identity documents. The rate of birth registration - usually the easiest vital statistic to collect - is a good proxy to assess the registering capacities of Sub-Saharan African states (Table). Although there are important country variations, estimates provide a picture of general failure.

As a consequence of their lack of state capacities, these countries face what have been called "second-order problems" of electoral integrity. ${ }^{11}$ These problems should not be underestimated. From the point of view of individual citizens, for instance electors wrongly excluded from the voter roll, the non-intentionality of breaches to electoral integrity might matter less than the denial of their rights. Moreover, the boundary between the political and the technical when it comes to elections is thin and electoral integrity is very much a matter of perceptions. ${ }^{12}$ In countries where trust between political actors is low and democracy is still fragile, technical insufficiencies can be easily politicized. Losing parties often claim fraud when technical irregularities have happened, whether because they misinterpret the situation or because they are trying to delegitimize the winner. In the most serious cases, violent contestation of electoral results can follow. But even when electoral violence is absent, the lack of trust in the electoral process can slowly undermine support for democracy itself.

On the other hand, low infrastructural power also facilitates the perpetration of actual electoral fraud. ${ }^{13}$ For instance, in the absence of adequate mechanisms for identifying eligible voters and detecting double registration, political parties may have an easy job in inflating the register with minors, foreigners or electors already registered. The issue of fraud in voter 
registration has become all the more prominent as international coverage of elections and electoral observation have reduced the scope for the most blatant forms of electoral fraud. ${ }^{14}$

As a consequence, in many developing countries, the issue of how to make voter registration 'safer' has become a prominent one. ${ }^{15}$ Opposition parties and civil society organizations have often been the most vocals in contesting existing voter rolls. However, incumbents have also pushed for reforming voter registration, in the hope of reinforcing their legitimacy in case of a new victory. International organizations such as the United Nations Development Programme (UNDP), the European Union (EU) and the International Foundation for Electoral System (IFES) have also been powerful agenda setters behind the modernization of voter registration. ${ }^{16}$

In the last few years, the adoption of computerized biometric technology, particularly Automated Fingerprint Identification Systems (AFIS), has featured particularly high in voter registration reform. The biometric industry in Sub-Saharan Africa has boomed, passing from 87.7 million USD in 2005 to 415.8 million USD in 2010, a growth per year of 37\%, higher than in any other world region. ${ }^{17}$ Much of this growth can be attributed to projects aiming at improving identification for general purposes, voter registration or both. Indeed, no less than twenty-four SubSaharan countries have already held elections with biometric registers (Table).

Arguably, the popularity of biometrics is linked to the fact that introducing a new votingrelated technology is easy compared to the long-term task of creating a reliable civil registration and identification system. However, while it can help with detecting double registration, biometrics cannot address the problem of the comprehensiveness of a voter list, nor help with telling who has the right to citizenship and who is a foreigner, and who has reached the age of voting and who is still a minor. ${ }^{18}$ Countries where national IDs and the civil register have limited coverage have been forced to establish special procedures to allow those who do not carry documents to register, particularly through some form of oral testimony.

In addition, while it narrows the space for certain forms of fraud, the adoption of Information Technology (IT) in elections might offer other opportunities to manipulate the electoral 
process, by placing “critical components of the process in a 'black box"” and making the observation of the voter registration process more difficult. ${ }^{19}$ This is all the more true as bids surrounding the provision of technology are not always awarded in a transparent manner.

A final problem with improving voter registration and identification is the blurred line between legitimate practices and fraud. A trade off between the accuracy and the inclusiveness of a voter list is to some extent inevitable. ${ }^{20}$ However, calls for for introducing more stringent requirements for being registered as a voter might be themselves a cover to disenfranchise potentially hostile voters. They are, in this regards, similar to legislative and administrative practices that, although presented as neutral, aim to restrict access to citizenship. ${ }^{21}$ Such a disenfranchisement, although conducted under the clout of the law, constitutes a substantial violation of democratic rights.

\section{Côte d'Ivoire and Ghana compared}

I now turn to at how, in practice, lack of 'registering capacities' and problems with voter registration have affected the consolidation of democracy in Côte d'Ivoire and Ghana. The two West African countries are easily amenable to a paired comparison. They are neighbours and share a similar geographical and climatic context. Their economy is based on a similar basket of natural resources, especially agricultural goods exported to the global market, such as cocoa and coffee. The two countries are ethnically and religiously diverse, with a large share of the population belonging to the Akan linguistic and ethnic family. Both face a geographical and ethnic NorthSouth divide, with a prevalently Muslim and relatively poorer North and a prevalently Christian and more prosperous South. Côte d'Ivoire and Ghana have a considerable population of foreign origin, who migrated from neighbouring countries attracted by the opportunities offered by cocoa farming.

Since independence, however, the political history of the two countries has sharply diverged. Ghana’s first ruler Kwame Nkrumah chose to embrace a variety of African socialism as his official ideology, but the experiment was short-lived, ending in a military coup and a long 
period of political instability and economic regression. In the same years, under the firm grip of his first ruler Félix Houphouët-Boigny, Côte d’Ivoire, an openly capitalist and pro-Western country, remained stable and achieved record rates of economic growth. However, since the 1980s, the two countries have experienced a sharp reversal in fortunes. ${ }^{22}$ After the military coup of Jerry Rawlings in 1979, Ghana’s economy started to recover, while Côte d'Ivoire’s economy showed signs of weakness.

At the beginning of the 1990s, the two countries have initiated a parallel process of political liberalization. However, while political opening has resulted in Ghana in the establishment of a democratic system, in Côte d’Ivoire the transition to democracy quickly stalled. The country experienced increasing political and ethno-regional tensions that culminated in the outbreak of a civil war in 2002 and in the subsequent occupation of the North of the country by the New Forces (NF) insurgents. After renewed crisis following the contested results of the 2010 presidential election, the country seems to have only recently embarked on the road to recovery.

Côte d’Ivoire and Ghana inherited from colonization and autocratic rule a deficient registration and identification system. The first ‘third wave' multi-party elections were controversial and the voter roll and the identification of voters posed particular problems. A number of efforts have since then been made in both countries to improve identification and voter registration and ease political tension, including the introduction of biometrics in Côte d'Ivoire’s 2010 presidential elections and Ghana’s 2012 presidential elections. However, while in Ghana innovations have been effective at generating trust in the electoral process, in Côte d'Ivoire political tensions have persisted and have been a significant factor behind the 2002 civil war. The process of post-conflict transition has eventually resulted in the elaboration of a voter roll accepted by all the parties but the list is in several respects still problematic.

The next two paragraphs review Côte d’Ivoire and Ghana's experiences with voter registration, before discussing more in depth some factors behind Ghana's relative success and Côte d'Ivoire’s failure. 


\section{Voter registration and identification in Côte d'Ivoire}

Côte d'Ivoire's civil registration system was created in colonial time ${ }^{23}$ but was extended to the whole territory only by the Félix Houphouët-Boigny regime. ${ }^{24}$ A National Identity Card was created in the early post-independence years but never achieved universal coverage. The rate of birth registration remained low, being estimated as late as in 2000 at $71.8 \% .{ }^{25}$ More worryingly, the status of the very large population of foreign origin was blurred. Houphouët-Boigny and his Parti Démocratique de la Côte d'Ivoire (PDCI) encouraged foreigners to settle in Côte d'Ivoire and even granted them the right to vote. As they did not risk deportation, many foreigners did not feel the urgency to apply for Ivorian citizenship, while others were able to obtain Ivorian identity documents outside the regular naturalization procedures.

However, the massive influx of foreigners, as well as of planters coming from other regions of Côte d'Ivoire , in the cocoa-producing areas of the South West of the country, caused tensions with the autochthonous population of these areas. These tensions were worsened by uncertain rules surrounding the access to land. The discontent of the 'autochtonous' culminated in a local armed revolt in 1970 that, although rapidly put down, was indicative of problems that were going to resurface in the '90s, in a context of economic crisis. ${ }^{26}$

The issue of the inscription of foreigners on the voter roll became a prominent one after the first multi-party elections in 1990. The elections were hold with a new consolidated list, exploiting data that the Institut National de la Statistique (INS) had collected in 1988 on the occasion of the general census. ${ }^{27}$ The regime granted the right to vote to foreigners "already registered”, ${ }^{28}$ a decision that was contested by Laurent Gbagbo, leader of the Front Populaire Ivoirien (FPI), the main opposition party, which had its stronghold in the South West. However, the fact that the president was reconfirmed with $81.7 \%$ of the votes suggests that he might have won even without the 'foreign vote'. 
The politicization of the citizenship question knew a further escalation with the death of Houphouët-Boigny in 1993 and the raise of a new opposition party, the Rassemblement des Républicains (RDR), which received the support of former Prime Minister Alassane Ouattara. The RDR was popular among second-generation immigrants and Northern Ivorians, culturally close to Burkinabe and Malians, and Ouattara was accused by his rivals of being himself of Burkinabé origin. ${ }^{29}$ Aiming at preventing Ouattara from standing in elections, Houphouët-Boigny’s successor Henri Konan Bédié promoted the divisive concept of ivoirité. The discourse of ivoirité tended to establish a distinction between 'true Ivorians' and Northerners, with the latter assimilated to immigrants. $^{30}$

In view of the 1995 elections, the Ivorian government made a substantial effort to respond to criticism about the voter list, which was however not sufficient to satisfy the opposition. ${ }^{31}$ The INS revised the list, extracting this time those who were identified as foreigners from it, ${ }^{32}$ and fully computerized it. However, given Côte d'Ivoire's deficient civil registration system, some foreigners were likely still able to vote. Furthermore, government and opposition were divided also about other issues, such as the nomination of an independent electoral commission and a controversial new electoral code, which stated that candidates to the presidency should be born by parents born Ivorians. The code was perceived by the RDR as an attempt to prevent Ouattara from running. Eventually, the RDR and the FPI launched a violent boycott of the 1995 elections, which reconfirmed Bédié, but in conditions of dubious legitimacy. ${ }^{33}$

In the following years, claims that foreigners had falsified or irregularly obtained birth certificates and national IDs and had used them to unduly register to vote resurfaced. The FPI broke its tactical alliance with Ouattara and embraced itself a xenophobic rhetoric, claiming to defend the rights of 'true' Ivorians, de facto identified with the autochthonous populations of the South Western region. An attempt was made to introduce new national IDs with security features, but the FPI claimed that foreigners had been able to obtain them illegally. ${ }^{34}$ On the other hand, the RDR was concerned with the possible exclusion of voters as a consequence of misguided attempts to 
'clean' the roll and to deliver IDs only to 'authentic' Ivorians. ${ }^{35}$ This fear intensified after the election of Gbagbo to the presidency in a contested poll in 2000, where Ouattara was again prevented from standing. The new regime launched a controversial process of identification of the population. ${ }^{36}$ Northern Ivoirians’ feeling of being stripped of their citizenship rights was a major factor behind the 2002 rebellion of the NF, which casted Côte d'Ivoire into a prolonged period of territorial division and political paralysis.

In 2007, following the initiative Gbagbo and NF leader Guillaume Soro themselves, the Ouagadougou Political Agreement (OPA) ${ }^{37}$ was concluded. Some observers qualified the agreement of "monumental shift" in the peace process, ${ }^{38}$ although doubts that were going to prove well-founded persisted about the good faith of the Ivorian parties in concluding it. ${ }^{39}$ The agreement paved the way to post-conflict elections and provided for a joint voter registration and identification process, with the aim to address the identification problems that had empoisoned Côte d'Ivoire's political climate.

A preliminary phase was envisaged for reconstructing the civil registries damaged or destroyed during the war. Citizens who did not hold a birth certificate had the possibility to be delivered one by presenting witnesses in front of mobile court judges, through the so-called audience foraines. However, the provisional voter roll was not only to be cleaned from doubles using biometric technology but also cross-checked with the 2000 electoral list and with a series of 'historical registries' of the Ivorian state, in order to establish beyond any doubt the citizen status of the potential electors. ${ }^{40}$ Moreover, in order to reassure the former conflict parties, the responsibility for the process was split among different actors. The INS was retained for technical expertise but the direction and supervision role was given to a new Independent Electoral Commission (IEC). Two additional bodies were in charge of the identification process for general purpose. ${ }^{41}$ French enterprise SAGEM was awarded the tender to produce new biometric IDs. There were polemics about how SAGEM had been selected and external donors refused to bear a major financial share of the joint voter registration-identification process. ${ }^{42}$ External partners remained however involved, 
as the UN Special Representative of the Secretary General (SRSG) was in charge to certify all stages of the electoral process. ${ }^{43}$

The joint process of identification and registration was launched on September 2008 and was long and chaotic. Instead of lasting 45 days, as originally planned, the collection of data extended up to nine months, among interruptions and resumptions. ${ }^{44}$ It was however with the processing of the biometric data in October 2009 that a major issue came out. 1033985 people whose names could neither be found in the 2000 list and in the historical registries nor identified as doubles or foreigners were excluded from the provisional voter list, hence labeled White List. A Grey List was created for gearing their case. ${ }^{45}$ In an attempt to determine the status of at least some of the people on the Grey List, Robert Beugré Mambé, president of the IEC, instructed its staff to carry a new cross checking using additional official registries. However, he was accused by Gbagbo’s supporters to have mismanaged the process and forced to resign in February $2010 .{ }^{46}$ Eventually, a compromise was found with the nomination of a new IEC president and the inscription of about 400000 people into the White List. The process resulted into the inscription on the final voter roll and the delivery of elector cards and national IDs to 5,725,722 Ivoirians. ${ }^{47}$

The list was certified by the UN SRSG and consensus about it made eventually possible the holding of post-conflict presidential elections in October and November 2010. However, the refusal of Gbagbo to acknowledge his defeat, as well as the ensuing conflict between the IEC and the Constitutional Council, loyal to the outgoing president, plunged the country into a renewed crisis, which resulted into the death of about 3000 people. ${ }^{48}$ In the end, thus, while the compilation of a voter list accepted by all the conflict participants was a necessary prerequisite for holding elections, it was per se unable to guarantee the acceptance of election results.

Also in view of this, and of the exorbitant cost of the process, several observers have questioned the outcome of the Ivorian joint voter registration and identification process. In spite of the long and complicate procedure, the Ivorian voter roll has several serious shortcomings. Following INS estimates, the list would have covered less than $73 \%$ of the potential voting 
population in $2010 .{ }^{49}$ Arguably, the Grey List still contains many electors unduly excluded from the vote. Moreover, in spite of having been used also for the 2011 legislative elections and the 2013 local elections, the list has no update mechanism and many new majors have as a consequence been excluded from the vote. ${ }^{50}$

Thus, although polemics about the presence of foreigners on the voter list have for the moment ceased, Côte d'Ivoire seems to have not found a satisfactory solution with its problem with registering and recognizing electors.

\section{Voter registration and identification in Ghana}

Ghana transitioned to democratic politics with an even weaker system of identification and registration of the population than Côte d'Ivoire. The country's vital registration system covered only about $40 \%$ of births in $1988^{51}$ and a project of introduction of a national ID card in 1970 had been interrupted before reaching national coverage. ${ }^{52}$

In Ghana, like in Côte d'Ivoire, the issue of voter registration has become prominent with the first multi-party election in 1992. The election, which former military ruler Jerry Rawlings won with a large margin, was hotly contested and the voter register was a cause of particular concern. ${ }^{53}$ Many voters could not present identity documents and were admitted to vote on a mere selfattestation. The New Patriotic Party (NPP), Rawling’s main opponent, published a pamphlet entitled The Stolen Verdict, ${ }^{54}$ where it claimed that the voter roll, which had initially been compiled for the District Assembly elections of 1988 and subsequently updated, contained two million 'ghost voters’, who had been key to ensure Rawlings’ victory. An ad hoc mission by IFES acknowledged the bloating of the voter roll, but concluded that it was due to technical and organizational shortcomings, rather than deliberate rigging, and that it had not substantially affected the result. ${ }^{55}$ Nonetheless, the refusal of the opposition to accept the verdict and its decision to boycott the subsequent parliamentary polls constituted a serious threat to the process of democratization. 
Ghana managed to overcome criticism in the short term thanks to the support of donors, particularly USAID and by IFES, which became strongly involved in the 1996 electoral process, ${ }^{56}$ and the installation in 1993 of an independent and permanent Electoral Commission (EC). ${ }^{57}$ The EC proceeded to compile a new voter register in October 1995, introducing two significant innovations: Optical Recognition Technology (OMR), which was used to facilitate the consolidation and computerization of the list and voter IDs with pictures, which made identification of voters easier. A special procedure was envisaged for people unable to present a birth certificate: they had to present two witnesses and, in case of contestation, their application was reviewed by a District Registration Review Committee. ${ }^{58}$ Another important move of the EC was the creation of the Inter Party Advisory Committee (IPAC), a loosely formalized body comprising representatives of political parties and of the EC, which provided a forum for political parties to engage in a dialogue with the EC and air their grievances. ${ }^{59}$

The new system was employed without major changes until the 2012 presidential elections. At the beginning, the EC's effort appeared successful at generating confidence in the electoral process by political parties and the general public. The 1996 elections were unanimously heralded as free and fair ${ }^{60}$ and, in 2000, Ghana crossed another step in its process of democratic consolidation with the peaceful transfer of power from Rawling's National Democratic Congress (NDC) to the NPP. ${ }^{61}$

However, concerns about the bloating of the voter register periodically resurfaced. In 2000, the EC itself admitted that the voter register contained about 1.5 million of 'ghost voters'. ${ }^{62}$ Given the low quality of the pictures on the voter cards, there was a risk that people could vote more than once, using the names of voters that had died or had moved. Registration of minors and foreigners was also a problem. ${ }^{63}$ Suspects that the NPP and the NDC were encouraging double voting or irregular registration, particularly in their respective strongholds, the Ashanti and Volta regions, were persistent. ${ }^{64}$ The EC periodically tried to 'clean' the register, but was unable to identify all the voters who had died or moved to another district. 
The 2008 elections, however, came as a watershed and convinced the Ghanaian EC that a new major reform of the voter registration process was needed. The election was extremely tight and the final difference in votes among the two main candidates was minimal: less than 50,000 votes over 9 million votes casted. The voter roll was particularly controversial. The EC was expecting to update it by adding about 800000 people: instead, 1.8 million turned out. ${ }^{65}$ The Coalition of Domestic Election Observers (CODEO) conducted a specific mission to observe the registration process and concluded that it had been marred by violence and irregularities. ${ }^{66}$ The Ashanti and Volta regions showed suspiciously high registration rates and voter turnout. ${ }^{67}$

Initially, the EC hoped that a breakthrough would have come from the implementation of Ghana’s parallel process of biometric identification. The process, started in 2008, was supposed to result in the delivery of national IDs with biometric features to all citizens aged more than 15, which should have been also employable to identify voters. However, the National Identification Agency, which lacked the human and financial resources of the EC, started soon to have problems of funding and, since December 2008, the process has de facto come to a halt. ${ }^{68}$

Against this backdrop, the EC decided to carry its own project of biometric registration. In what has probably been the most ambitious experiment up to date with biometrics in an African election, the EC aimed not only at employing biometric to vet and de-duplicate the data, but also for the verification of the identity of voters at polling stations, which was to be performed by scanning the voters' fingers with verification machines. This solution was particularly appropriate to deal with issues of multiple registration and impersonation.

The registration of voters, carried in 2012, a few months ahead of presidential elections, was fairly successful. 14060573 people were registered in only 40 days. The provisional list was then put on display and a number of voters were subtracted or added following objections on the list, leading to a final electoral list including 14031793 people. ${ }^{69}$ Perhaps more importantly, the process received a positive assessment by the general public. According to a survey conducted by CODEO among Ghanaian registered to vote, $78 \%$ of respondents agreed the biometric registration 
represented an improvement with respect to the old system and $87 \%$ of respondents considered it a useful tool for promoting credible and peaceful elections. ${ }^{70}$

The implementation of the new biometric verification system on election day experienced however certain technical difficulties. The EC insisted before the elections that no one would be allowed to vote without their identity being verified biometrically. ${ }^{71}$ However, biometric machines failed at some point during voting at $19 \%$ of polling stations and the EC was forced to extend the voting of one day. ${ }^{72}$ The NPP filled a complaint, which has now been rejected, at the Ghanaian Supreme Court. It alleged among other things that some polling station officials had resorted to double standards, allowing some electors to vote without biometric verification. ${ }^{73}$

In the end, although polemics about the voter register have been a recurrent feature of postdemocratization Ghana, the country has been able to overcome them fairly well and to avoid that they jeopardize democratization. Although some observers have pointed out at the recent NPP complaint in order to argue that elections have become more controversial, ${ }^{74}$ contestation has not turned violent. Parties have resorted to the existing legal mechanisms and, in fact, the complaint appears to have reinforced the legitimacy of the biometric system. It must be also pointed out that the Ghanaian voter register is currently considered one of the most reliable databases of the country. It has found an application in a number of non-electoral domains, such as the banking and education system, thus generating additional benefits. ${ }^{75}$

\section{Ghana's success and Côte d'Ivoire's failure discussed}

Why has Ghana been able to compensate for its deficit in 'infrastructural power', while in Côte d'Ivoire polemics about voter registration and identification have continued to empoison the democratic debate for a long time? I discuss below some of the factors that explain Ghana's relative success with respect to Côte d'Ivoire. Some pertain to the more general political context, such as the politicization of the citizenship question in Côte d'Ivoire but not in Ghana. Others revolve 
around the electoral process itself, such as the role of the electoral administration, and the gradualist approach to technological innovation in Ghana.

\section{The citizenship question and its politicization}

Countries that inherit a deficient civil registration system and where many people do not hold identity documents have to strike a balance between inclusivity and accuracy when compiling their voter rolls. Finding a solution to this dilemma is a particularly thorny issue, because it exposes the subtle line between acceptable administrative practices and legally sanctioned violation of democratic rights. In particular, a political consensus has to be found on the nationality of applicants: a more relaxed system will probably be unable to avoid that some foreigners register, but a more rigid system will run the opposite risk of excluding citizens from the vote.

Although both in Ghana and Côte d'Ivoire there have been justified concern that some foreigners were able to enroll, Ghana has not experienced a politicization of the citizenship question comparable to Côte d'Ivoire. In spite of the presence of a considerable migrant population, several issues have prevented Ghana from embarking on the same path. First, there is not an equivalent land tenure problem in Ghana, as the autochthonous population of the cocoa producing areas has been able to negotiate the access of migrants to land on favourable terms. ${ }^{76}$ Second, Ghana's community of foreign origin mobilized early for its rights and obtained the legal recognition of citizenship before democratization. Free elections have further benefited second generation migrants, as they have regularly sanctioned political actors that appeared unfavourable to them. ${ }^{77}$ Thus, Ghanaian stakeholders have accepted that the nationality of the applicant could be established through the statement of witnesses, while in Côte d'Ivoire the FPI's obsession with the presence of foreigners on the voter list has led in 2010 to the establishment of extra mechanisms to verify the nationality of applicants. However, because these mechanisms have arguably been unable to capture all Ivorian citizens, many potential voters have been excluded from the roll. 
In retrospective, coupling the processes of identification and voter registration for the 2010 post-conflict elections seems to have contributed in Côte d'Ivoire to the extreme politicization of the process. ${ }^{78}$ It shall also be noticed, however, that in Ghana, the opposite choice to keep the two processes separate has resulted in a duplication of financial efforts. Had Ghana been able to complete the process of introduction of the new biometric ID card, it could have enhanced voter identification without changing its system of voter registration. ${ }^{79}$

\section{The role of the electoral administration}

The importance of an autonomous electoral management body for new democracies has been often acknowledged. ${ }^{80}$ In Côte d'Ivoire, because of, among others, French colonial heritage and lack of political negotiations on electoral governance, ${ }^{81}$ the first multi-party elections were held under the supervision of the Ministry of Interior. ${ }^{82}$ The current IEC, which oversaw the process of biometric voter registration, has enjoyed more autonomy, but has other deficiencies that have affected its capacity to register voters effectively. It has been created as an 'ad hoc' and temporary institution as the result of peace negotiations. It is a plethoric political body, composed by representatives of parties and former rebel movements, which initially had little or no experience at administering an election. The participation of other four structures to the joint voter registration and identification process has been an additional source of inefficiencies and delays. ${ }^{83}$

In Ghana, the Interim National Electoral Commission (INEC) that supervised voter registration for the 1992 elections was also accused of partiality. The 1993 Electoral Commission Act, however, contains detailed provisions aiming at securing the independence and autonomy of

the EC. ${ }^{84}$ In contrast to Côte d'Ivoire’s IEC, Ghanaian EC members are permanently appointed civil servants, not political representatives. They regard themselves as professionals of elections and have accumulated a substantial amount of technical knowledge through time. ${ }^{85}$ At critical junctures, such as the controversial 2008 election, perceptions of the public that, whatever the problems with the voter register, the EC was sincerely committed to organizing free and fair elections, has been 
key in repelling the risk of electoral violence. ${ }^{86}$ The existence of the IPAC, moreover, has allowed political parties to voice their concerns without hijacking the electoral administration. Indeed, the disputes that have followed the 2012 election have been attributed to the EC failure to properly involve the IPAC, in contrast with previous elections. ${ }^{87}$

Contrasting Côte d’Ivoire and Ghana suggests that autonomy and professionalism are both necessary conditions for effective electoral governance. The Ghanaian EC has been successful because it embodies both qualities. In Côte d'Ivoire the INS enjoyed technical expertise, but was seen as a government-controlled organization by the opposition and was thus unable to play a similar role.

\section{The approach to introduction of technology}

The professionalism of the Ghanaian EC has also shaped the way the country has approached the issue of technological innovation. Differently than in other developing countries, the Ghanaian

voter register has evolved gradually. ${ }^{88}$ At the beginning, the EC relied on the technical and financial assistance of donors, but has become progressively more autonomous. OMR was chosen because it had already been used in the education system, and many poll officials, who were local teachers, were familiar with it. The EC first adopted Polaroid cameras, then substituted then with digital cameras. The adoption of biometrics was a meditated decision and the Ghanaian EC wanted to make the most of the new technology. The tender process was strict, with 47 companies screened before the decision to award the bid to STL/HSB/Genkey company. ${ }^{89}$

At the beginning of the ' $90 \mathrm{~s}$, due to the efforts of the INS to improve the voter registration process in a sustainable way, Côte d'Ivoire seemed embarked on the same path as Ghana. However, the political crisis has interrupted the process of technical learning. The 2007-2010 voter registration and identification process was planned in a context of post-conflict elections, in substantial discontinuity with the previous voter registration exercises. Paradoxically, instead of contributing to make the process more consensual, new technologies have generated suspicions and 
mistrust. ${ }^{90}$ The attribution of the tender to French enterprise SAGEM has been particularly controversial, as many in Côte d'Ivoire thought that corruption and political considerations president Gbagbo was trying to improve his relationships with France - had played a role in the choice.

A cause of concern in both Ghana and Côte d'Ivoire is the cost of registration, which biometrics has contributed to increase. Côte d'Ivoire's 2010 election has been regarded as one of the most expensive ever held. ${ }^{91}$ Because of the continuous delays, the cost of voter registration levitated: according to IEC and UNDP estimates, the expenses amounted in the end to about 312 million USD. ${ }^{92}$ Most of this sum was absorbed by the SAGEM contract, which increased with respect to the initial bid and reached 266 million USD. In Ghana, although the process has been more cost-effective, the financial burden has not ceased to grow since the '90s. ${ }^{93}$ The 2012 biometric exercise has cost about 149 million CEDI, or 53 million USD, ${ }^{94}$ although, in positive, the Ghanaian authorities were able to sustain the expenses without direct donor contributions. ${ }^{95}$

\section{Conclusion}

The quality of an election is determined not only by the deliberate will of political actors to abide the rules or to fraud, but also by the infrastructural capacities of the state. Registration and identification techniques and technologies are a component of state capacities that has a particularly strong impact on elections, as from them depends the compilation of a comprehensive and accurate voter list and the identification of people entitled to vote. At the beginning of their process of democratization, Ghana and Côte d’Ivoire faced similar challenges. Ghana has responded by instituting an independent and professional electoral administration, which has experimented with a series of technical innovations in order to make the electoral process safer. On the other hand, in Côte d'Ivoire, the politicization of the citizenship question and the subsequent descent of the country into political turmoil have prevented the elaboration of a voter list accepted by all political parties. The current voter and population rolls, although a consensus has been found on them, still 
exclude a considerable number of citizens. The paradox of voter registration is that a good voter register is necessary to generate trust in the electoral process, but the elaboration of a good quality register requires trust in the electoral administration and a relatively consensual political climate. Côte d'Ivoire has been dragged into a vicious circle, while in Ghana the role of the EC has been fundamental in overcoming both political and technical challenges.

A considerable, although underestimated risk, is also that 'safer' registration systems may trade accuracy and currency for comprehensiveness, resulting in the legal disfranchisement of voters. In Côte d’Ivoire, the system implemented in 2010 has led to the exclusion of many potential voters.

During their last voter registration exercise, Ghana and Côte d'Ivoire have both tried to make their voter list more reliable by introducing biometrics. However, their example show that technology in elections is not a magic stick, but its impact is mediated by the political and institutional context. Moreover, technology cannot really address problems such as the registration of foreigners or minors. A long-term solution to these issues could only come from a long-term work of reinforcement and modernization of the civil registration and identification system. Unfortunately, governments and donors alike seem up to now to have paid more attention to short term considerations linked to electoral deadlines. The ill-fated experience of Ghana with national identification shows that synergies are not duly exploited.

On the other hand, although voter registration is in most of the cases non-compulsory, in countries where most citizens do not hold a national ID, it is often the easiest way for citizens to obtain an identity document. Thus, the voter registration process itself can be perceived as a part of the process of statebuilding and of reinforcement of the infrastructural reach of the state. ${ }^{96}$ 


\section{Acknowledgements}

I would like to thank Astrid Evrensel, Hubert Akumiah, Fred Tetteh and Said Bacar Houssein for helping me with finding data on the Ghana and Côte d'Ivoire voter registration processes.

Nkwachukwu Julius Orji, Diego Garzia and Philipp Trotter read an earlier version of the paper and provided useful comments on it. Although the article has not directly benefited from project funding, many of the ideas presented here have been developed while working with Giovanni Carbone and the team of the project "The economic, social and political consequences of democratic reforms”, to whom also goes my gratitude.

\section{Funding}

This paper has been written at the German Institute of Global and Area Studies (GIGA) while benefitting of a post-doctoral fellowship funded by the Alexander Von Humboldt Stiftung. I was able to hold some interviews in Accra while conducting a parallel research project on regional organizations and conflict transformation in West Africa. My stay in Ghana was funded by Compagnia di San Paolo, through the programme "Europe and Global Challenges" together with Volkswagenstiftung and Riksbankens Jubileumsfondet.

1. Pastor, 'The Role of Electoral Administration', 2.

2. Norris, ‘The New Research Agenda’; Elklit and Reynolds, ‘A Framework for the Systematic Study’;

Kelley ‘Data on International Elections’.

3. Leloucq, ‘ Electoral Fraud’; Birch, ‘Electoral Malpractice’; Schedler, ‘Elections without Democracy’; Lopez-Pintor, 'Assessing Electoral Fraud'.

4. Mann, 'The Autonomous Power of the State'; Mann, 'Infrastructural Power Revisited'.

5. Fortin-Rittberger. 'The Role of Infrastructural and Coercive State Capacity’, 96.

6. Breckenridge and Szreter, Registration and recognition.

7. ACE, 'Voter registration'.

8. Elklit and Reynolds, ‘A Framework for the Systematic Study’; Kelley, 'Data on International Elections’; Birch, Electoral Malpractice; Norris, 'Perceptions of Electoral Integrity’.

9. Evrensel, 'Voter Registration in Africa'.

10. Setel et al., 'A Scandal of Invisibility'.

11. Norris, 'The New Research Agenda’, 566.

12. Pastor, ‘The Role of Electoral Administration'; Norris, ‘The New Research Agenda’; Fortin-Rittberger.

‘The Role of Infrastructural and Coercive State Capacity’.

13. Fortin-Rittberger. 'The Role of Infrastructural and Coercive State Capacity’.

14. Ichino and Schündeln, 'Deterring or Displacing Electoral Irregularities?'. 
15. ACE, 'Voter Registration Trends'; Evrensel, 'Voter Registration in Africa’.

16. Evrensel, 'Voter Registration in Africa'; Yard, 'Civil and Voter Registries'.

17. Gelb and Clark, 'Identification for Development', 66.

18. Evrensel, 'Voter Registration in Africa'.

19. Evrensel, 'Voter Registration in Africa’, 3.

20. Gelb and Clark, 'Identification for Development'.

21. Geschiere, 'The Perils of Belonging'.

22. Eberhard and Teal, 'Ghana and Côte d'Ivoire’.

23. Cooper, 'Voting, Welfare and Registration'.

24. UNICEF, ‘Enquête à Indicateurs Multiples’, 48.

25. UNICEF, ‘Enquête à Indicateurs Multiples’ .

26. Marshall, 'The War of Who is Who'. For a broader discussion of the politics of autochthony, see Geschiere, The Perils of Belonging.

27. Interview with former INS officer.

28. Crook, 'Winning Coalitions', 222.

29. Akindès, 'The Roots of the Military-Political Crises’; Dembelé, 'La Fracture Communautaire’.

30. Akindes, ‘The Roots of the Military-Political Crises’; Losch, ‘Côte d’Ivoire, la Tentation Ethnonationaliste’.

31. Crook, ‘Winning Coalitions’, 231.

32. Interview with former INS official.

33. Crook, 'Winning Coalitions'.

34. Dembelé, 'La Fracture Communautaire’.

35. Marshall, 'The War of 'Who is Who'”

36. Dembelé, 'La Fracture Communautaire'; Marshall, 'The War of 'Who is Who’’.

37. Republic of Côte d’Ivoire, 'Accord Politique de Ouagadougou'.

38. Bah, 'Democracy and Civil War', 610.

39. Handy and Charles, 'L’Accord Politique de Ouagadougou'. Piccolino, 'David against Goliath'.

40. Adou and Lam, 'Identification-Enregistrement Electronique’. 
41. Ibid.

42. Barry and Konaté, 'Rapport d’Evaluation'.

43. Théroux-Bénoni, 'Lessons for UN Electoral Certification'.

44. The Carter Center, 'International Election Observation. Report 1'.

45. Adou and Lam, 'Identification-Enregistrement Electronique’; UNOCI, 'Identification générale des Populations'.

46. ICG, 'Côte d’Ivoire: Sécuriser le processus’.

47. Adou and Lam, ‘Identification-Enregistrement Electronique’; UNOCI, ‘Identification générale des Populations'.

48. Piccolino, ‘David against Goliath’.

49. The Carter Center, 'International Election Observation. Final Report', 30.

50. Bouquet and Kassi-Djodjo, 'Les Elections Locales 2013’.

51. Ghana Statistical Service, ‘Demographic and Health Survey’, 2.

52. Breckenridge, 'The World’s First Biometric Money’.

53. Jeffries and Thomas, 'The Ghanaian Elections of 1992'; Lyons, 'Ghana’s Encouraging Elections’.

54. New Patriotic Party, The Stolen Verdict.

55. Jeffries and Thomas, 'The Ghanaian Elections of 1992'.

56. Smith, ‘Consolidating Democracy?’; Holtved, ‘Ghana’.

57. Lyons, ‘Ghana’s Encouraging Elections’; Jeffries, ‘The Ghanaian Elections of 1996’.

58. Holtved, ‘Ghana’.

59. Asante. 'Making Democracy Work’.

60. Jeffries, 'The Ghanaian Elections of 1996’.

61. Smith, 'Consolidating Democracy?’.

62. Smith, 'Consolidating Democracy?, 624.

63. Holtved, ‘Ghana’; Jockers, Kohnert and Nugent, ‘The Successful Ghana Elections of 2008’; Ichino and Schündeln, 'Deterring or Displacing Electoral Irregularities?’.

64. Smith, 'Consolidating Democracy?’; Jockers, Kohnert and Nugent, 'The Successful Ghana Elections of 2008'. 
65. Jockers, Kohnert and Nugent, 'The Successful Ghana Elections of 2008'; Ichino and Schündeln,

'Deterring or Displacing Electoral Irregularities?'.

66. Ichino and Schündeln, 'Deterring or Displacing Electoral Irregularities?'.

67. Jockers, Kohnert and Nugent, 'The Successful Ghana Elections of 2008'.

68. Breckenridge, ‘The World’s First Biometric Money’.

69. EC, ‘2012 Exhibition Statistics’.

70. CODEO, ‘Final Statement.

71. Omotola, 'The Electoral Commission of Ghana'.

72. CODEO, 'Preliminary Statement'. Aiyede, Erameh and Orimolade, 'The Institutional Framework'.

73. Omotola. 'The Electoral Commission of Ghana', 49; Kelly and Bening, 'The Ghanaian Elections of 2012'.

74. Omotola, ‘The Electoral Commission of Ghana’. Asante, ‘Making Democracy Work'.

75. Interview with former EC official.

76. Mitchell, Insights from the Cocoa regions.

77. Kobo, “We are citizens too”".

78. Interview with IEC official.

79. Holtved, 'Ghana’.

80. Mozaffar, 'Patterns of Electoral Governance'; Gazibo, Mamoudou. 'The Forging of Institutional Autonomy’; Fall, Hounkpe, Jinadu and Kambale. ‘Election Management Bodies’.

81. Mozaffar, 'Patterns of Electoral Governance’; Gazibo, Mamoudou. 'The Forging of Institutional Autonomy’.

82. Crook, 'Winning Coalitions'.

83. Adou and Lam, 'Identification-Enregistrement Electronique'.

84. Jeffries, 'The Ghanaian Elections of 1996'.

85. Debrah, Asante, and Gyimah-Boadi. 'A Study of Ghana’s Electoral Commission’.

86. Whitfield, 'Change for a Better Ghana’; Fall, Hounkpe, Jinadu and Kambale, Election Management Bodies.

87. Asante, 'Making Democracy Work' 
88. Holtved, ‘Ghana’, 100.

89. Interview with former EC official.

90. Adou and Lam, 'Identification-Enregistrement Electronique’.

91. Airault and Mieu, ‘Les Bonnes Affaires’.

92. Adou and Lam, 'Identification-Enregistrement Electronique’; Barry and Konaté, 'Rapport d’Evaluation’.

93. Holtved, ‘Ghana’.

94. Ghana Election 2012, '20 Fascinating Facts'.

95. Interview with former EC official.

96. Slater, ‘Can Leviathan be Democratic?’; Piccolino, ‘Making Democracy Legible’. 


\section{Bibliography}

ACE Electoral Knowledge Network. 'Voter Registration trends and practices around the world'. 2006. http://aceproject.org/electoral-advice/archive/questions/replies/699408087

ACE Electoral Knowledge Network, ‘Voter Registration’, n.d. http://aceproject.org/ace-en/topics/vr.

Adou, Antoine and Moktar Lam. 'Identification-enregistrement électronique de la population et des électeurs: cas de la Côte d'Ivoire'. Presentation at Thematic Workshop 'Information Technology and Elections Management', European Commission - United Nations Development Programme (ECUNDP) Partnership on Electoral Assistance, Mombassa, Kenya, March 5-9 2012.

http://ec-undpelectoralassistance.org/index.php?option=com_content\&view=article\&id=170\&Itemid=176\&lang=en

E. Remi Aiyede, Nicholas Idris Erameh and Oluwatosin S. Orimolade, 'The Institutional Framework of the 2012 Elections In Ghana. Consolidating or Reversing Democratic Achievement?’. Journal of African Elections 2, no. 2 (2013): 13-33.

Akindès, Francis. The Roots of the Military-Political Crises in Côte d'Ivoire. Uppsala: Nordiska Afrikainstitutet, 2004.

Asante, Richard. 'Making Democracy Work? Quasi-Public Entities and the Drama of Elections in Ghana' Journal of African Elections 2, no. 2 (2013): 56-74.

Abu Bakarr Bah, 'Democracy and Civil War. Citizenship and Peacemaking in Côte d'Ivoire', African Affairs 109, no. 437 (2010), 597-615.

Barry, Mamadou B., and Maïmouna Konaté. 'Rapport d’évaluation du programme d’appui au processus électoral en Côte d’Ivoire (PAPE 2008-2012)’. Abidjan: UNDP, 2013.

Bouquet, Christian, and Irène Kassi-Djodjo. 'Les élections locales 2013 en Côte d’Ivoire: des malentendus subsistent sur l'exercice de la démocratie'. EchoGéo on line, 2014. http://echogeo.revues.org/13697.

Breckenridge, Keith. 'The world’s first biometric money: Ghana's e-Zwich and the contemporary influence of South African biometrics'. Africa 80, no. 4 (2010): 642-662.

Breckenridge, Keith, and Simon Szreter, eds. Registration and Recognition: Documenting the Person in World History. Oxford: Oxford University Press, 2012. 
Coalition of Domestic Observers (CODEO). 'Final Statement on the observation of the nationwide

Biometric Voter Registration (BVR) exercise’. 2012.

http://codeoghana.org/index.php/coalition-of-domestic-election-observers-codeo-final-statement-on-theobservation-of-the-nationwide-biometric-voter-registration-exercise.

CODEO ‘Preliminary Statement on Ghana’s December 7 to 82012 Presidential and General Elections’. 2012. http://www.codeoghana.org/images/CODEO_Preliminary_statement-2012_1.pdf

Crook, Richard. 'Winning Coalitions and Ethno-Regional Politics: the Failure of the Opposition in the 1990 and 1995 Elections in Côte d'Ivoire’. African Affairs 96, no. 383 (1997), 215-242.

Dembelé, Ousmane. ‘Côte d’Ivoire: la fracture communautaire’. Politique Africaine, no. 89 (2003): 34-48.

Debrah, Emmanuel, E. Kojo Pumpuni Asante, and Emmanuel Gyimah-Boadi. A Study of Ghana's Electoral Commission. CODESRIA Research Reports, no. 2, 2010.

Eberhard, Markus, and Francis Teal. ‘Ghana and Côte d’Ivoire: Changing Places’. International Development Policy, no. 1 (2010): 33-49.

Evrensel, Astrid, ed. Voter Registration in Africa: A comparative analysis. Johannesburg: Electoral Institute for the Sustainability of Democracy in Africa (EISA), 2010.

Fall, Ismaila Madior, Mathias Hounkpe, Adele L. Jinadu, Pascal Kambale. Election Management Bodies in West Africa. A comparative study of the contribution of electoral commissions to the strengthening of democracy. Johannesburg: Open Society Initiative for West Africa, 2011.

Fortin-Rittberger, Jessica. 'The role of infrastructural and coercive state capacity in explaining different types of electoral fraud'. Democratization 21, no. 1 (2014): 95-117

Gazibo, Mamoudou. 'The Forging of Institutional Autonomy: A Comparative Study of Electoral Management Commissions in Africa'. Canadian Journal of Political Science/Revue canadienne de science politique 39, no. 3 (2006): 611-633.

Gelb, Alan, and Julia Clark. ‘Identification for Development: The Biometrics Revolution’. Working Paper 315, Center for Global Development, New York, 2013.

Ghana Election 2012 Website. '20 Fascinating Facts and Figures on Ghana’s Biometric Voter registration’. 2012. 
http://www.africanelections.org/ghana/news_detail.php?nws=6117\&t=20\%20Fascinating\%20Facts\%2 0and\%20Figures\%20on\%20Ghana’s\%20Biometric\%20Voter\%20registration.

Ghana Statistical Service and Ghana Health Service. 'Demographic and Health Survey’. 2008.

Toussaint Charles and Simon P.A. Handy, 'L'Accord politique de Ouagadougou: vers une sortie de crise pérenne en Côte d'Ivoire?’, Annuaire Français de Relations Internationales 9 (2008) : 653-67.

Holtved, Ole. 'Ghana'. In Voter Registration in Africa, edited by Astrid Evrensel, 102-126.

Ichino, Nahomi and Matthias Schündeln. 'Deterring or Displacing Electoral Irregularities? Spillover Effects of Observers in a Randomized Field Experiment in Ghana’. The Journal of Politics 74, no. 1 (2012): 292-307.

International Crisis Group (ICG). ‘Côte d’Ivoire: sécuriser le processus électoral’. Africa Report 158, 2010. Jeffries, Richard. 'The Ghanaian elections of 1996: towards the consolidation of democracy?' African Affairs 97, no. 387 (1998): 189-208.

Jockers, Heinz, Dirk Kohnert and Paul Nugent. ‘The successful Ghana election of 2008: a convenient myth?’. Journal of Modern African Studies 48, no.1 (2010): 95-115.

Kelly, Bob, Bening, R. B. 'The Ghanaian elections of 2012'. Review of African Political Economy 40, no. 137 (2013): 475-484.

Kelley, Judith. 'Data on International Election Monitoring: Three Global Datasets on Election Quality, Election Events and International Election Observation’. Ann Arbor, MI: Inter-university Consortium for Political and Social Research [distributor], 29 August 2014. http://doi.org/10.3886/ICPSR31461.v2

Kobo, Ousman. 'We are citizens too': the politics of citizenship in independent Ghana'. The Journal of Modern African Studies, 48, n.1 (2010): 67-94.

Losch, Bruno, ed. 'osch, Bruno, ed. ern African Studies the politicPolitique Africaine, no. 78 (2000): $5-156$.

Lyons, Terrence. 'Ghana’s Encouraging Elections: a major step forward?’. Journal of Democracy 8, no. 2 (1997): 65-77.

Marshall, Ruth. ‘The War of 'Who Is Who': Autochthony, Nationalism, and Citizenship in the Ivorian Crisis'. African Studies Review, 49, no. 2 (2006): 9-43. 
Mitchell, Matthew I. 'Insights from the Cocoas Region in Côte d'Ivoire and Ghana: Rethinking the Migration-Conflict Nexus’. African Studies Review 54, no. 2 (2011), 123-124.

Mozaffar, Shaheen. 'Patterns of Electoral Governance in Africa’s Emerging Democracies'. International Political Science Review 23, no. 1 (2002), 85-101

New Patriotic Party (NPP). The Stolen Verdict: Ghana, November 1992 Presidential Elections. NPP, Accra, 1993.

Omotola, Joshua. 'The Electoral Commission of Ghana and the Administration of the 2012 Elections', Journal of African Elections 2, no. 2 (2013): 34-55.

Norris, Pippa. ‘The new research agenda studying electoral integrity'. Electoral Studies 32 (2013): 563-575.

Pastor, Robert. 'The role of electoral administration in democratic transitions: Implications for policy and research’. Democratization 6, no. 4 (2006): 1-27.

Piccolino, Giulia. 'Making democracy legible? The politics of voter registration and the experience of the Permanent Electronic Electoral List in Benin’. Development \& Change, forthcoming.

Piccolino, Giulia. ‘David against Goliath in Côte d’Ivoire? Laurent Gbagbo’s war against Global Governance'. African Affairs 111, no. 442 (2012): 1-23.

Pryce, Paul, and Raphael Oidtmann. 'The 2012 General Election in Ghana’. Electoral Studies 34 (2013): 330-334.

Republic of Côte d'Ivoire. 'Accord Politique de Ouagadougou (APO)', 4 March 2007. Edition including complementary agreements and implementing decisions. Abidjan: Centre d'Information et de la Communication Gouvernementale, 2009.

Schedler, Andreas. 'Elections without Democracy: the Menu of Manipulation'. Journal of Democracy 13, no.2 (2002): 36-50.

Setel, Philip W., Sarah B. Macfarlane, Simon Szreter, Lene Mikkelsen, Prabhat Jha, Susan Stout, Carla Abou Zahr. 'A scandal of invisibility: making everyone count by counting everyone’. The Lancet 370, n. 9598 (2007): 1569-1577.

Smith, Daniel A. 'Consolidating democracy? The structural underpinnings of Ghana's 2000 elections’. Journal of Modern African Studies 40, no. 4 (2002): 621-650. 
The Carter Center. 'International Election Observation Mission to Côte d'Ivoire. Report 1, Observation of Identification and Voter Registration’. December 2008.

The Carter Center. 'International Election Observation Mission to Côte d'Ivoire. Final Report, 2010 Presidential Elections and 2011 Legislative Elections’. 2012.

Slater, Dan. 'Can Leviathan be democratic? Competitive elections, robust mass politics, and state infrastructural power'. Studies in Comparative International Development 43, 3-4 (2008): 252-272.

Whitfield, Lindsay. 'Change for a Better Ghana: party competition, institutionalization and alternation in Ghana’s 2008 elections'. African Affairs 108, 433 (2009): 621-641.

Yard, Michael, ed. Civil and Voter Registries: Lessons Learned from Global Experiences. Washington: International Foundation for Electoral Systems (IFES), 2011. 